This item was submitted to Loughborough's Research Repository by the author.

Items in Figshare are protected by copyright, with all rights reserved, unless otherwise indicated.

\title{
Welfare state international
}

PLEASE CITE THE PUBLISHED VERSION

https://www.bloomsbury.com/uk/british-theatre-companies-1965-1979-9781408175439/

\section{PUBLISHER}

Bloomsbury

VERSION

VoR (Version of Record)

\section{PUBLISHER STATEMENT}

This work is made available according to the conditions of the Creative Commons Attribution-NonCommercialNoDerivatives 4.0 International (CC BY-NC-ND 4.0) licence. Full details of this licence are available at: https://creativecommons.org/licenses/by-nc-nd/4.0/

\section{LICENCE}

CC BY-NC-ND 4.0

\section{REPOSITORY RECORD}

Whiteley, Gillian. 2019. "Welfare State International”. figshare. https://hdl.handle.net/2134/37311. 


\section{Chapter 7}

\section{WELFARE STATE INTERNATIONAL}

Gillian Whiteley

\section{Introduction}

The Welfare State exists to create images in the most unexpected places: in streets, on housing estates, on recreation grounds. A labyrinth made out of junk is sprayed white by the fire brigade with labyrinth made out of junk is sprayed white by the A burning coracle is thrown into a grey canal. In the drabbest of circumstances, the Welfare State plays out the role of permanent Lords of Misrule. (Albert Hunt quoted in Craig, 1980, 25)

Given its longevity alone, it would be difficult to overstate Welfare State International's significance in relation to the histories of performance art: alternative, experimental and applied theatre and participative art: alternative experimental 1968 and 2006, this collective of artists forms of practice. Between 1968 and 2006, this collective or artists, writers, musicians, performers and engineers pioneered site-specific multimedia theatre and processional street performance, and developed multimedia theatre and procession new models of community art. Rooted in the radical counter large-scale contexts of the 1960s, their ambitious events combined large-scale spectacle and popular theatre, attracting international acclaim and directly spawning a wide range of other experimental theatre companies do and performance as the iconic Parliament in Flames (1976), first staged in Burnley with an audience of over 10,000 people, 'no-one else was in Burnley with an audience of over 10,000 pers (Kershaw, 1992 212). producing carnivalesque agit prop on this scal

By the 1980 s, consolidated in the publication of Tony Coult and Baz Kershaw's co-authored book Engineers of the Imagination, The Baz Kershaw's Co-albok (Coult and Kershaw, 1983), a DIY guide to Welfare State Handbook (Coult and Kershaw, 1983), a DIY guide to basic techniques aimed at sharing their ethos, skills and practices with others, they had developed new forms and prototypes of vernacular others, the passage, such as arts and theatre. Celebratory theatre, secular rites of panture Welfare 'naming ceremonies', and lantern adopted by other companies and arts State practices that were wider encountering 
the Lantern Sea Ceremony in Northern Japan in 1982, Welfare State devised the first Lantern Festival at their base in Ulverston in 1983 and this became an annual community-based event (Fox, 2002, 75-6) spawning many other similar festivals across the UK. Since 2006, Joh Fox and Sue Gill have continued to develop alternative rites and ritual through, for example, the expansion of a series of practical handbooks, the Dead Good Guides. Welfare State's valedictory show, Longline, the Carnival Opera (2006), Welfare State's valedictory show, Longline, the Carnival Opera (2006), was performed in a circus tent at Low Mill Business Park, Ulverston. The multimedia performance synthesized a range of recurrent themes, narratives and images from forty years' work, while investigating the contemporary political economies and ecological issues around Morecambe Bay. Recurrent Welfare State themes were interwoven with current reflections on the plight of migrant workers, the environmental consequences of nuclear power, the role of local arms and pharmaceutical industries, the impact of local tourism and the effects of global warming. Combining the key elements of spectacle and participation, Longline involved over five hundred performers and included many familiar Welfare State components community choirs, acrobats, puppetry, live music and a processional lantern finale with fireworks - inviting reflection on its own history back to its origins as a radical itinerant company in 1968 .

The rapid expansion of all forms of alternative theatre in the 1970s has been well documented. However, it is worth emphasizing that, besides this being one of their most creative and productive periods, Welfare State was particularly astute at capitalizing on the 'subsidy revolution' in the 1970s. Under Thatcherite policies, the 'market-orientated' 1980s witnessed the demise of many politica theatre groups and, as Bim Mason indicated in 1992, the virtual disappearance of such activities outdoors' (Mason, 1992, 3). However while many other companies folded, Welfare State demonstrated while many other companies folded, Welfare State demonstrated a remarkable capacity to adapt; as Mason noted, through that difficult period, the company continued to flourish but it also managed to maintain artistic integrity at the same time as retaining their 'political edge' (Mason, 1992, 24).

\section{Spectacle and Participation: Rethinking Critical Contexts}

Mason's association of their work with 'the political' raises the question of how Welfare State has been positioned critically and historically. Since the 1970s, there has been an intense critical debate around definitions and discourses related to 'alternative', 'popular', 'fringe, 'political', 'avant-garde', 'experimental' and 'community' theatre. The longevity of the company, its ever-changing personnel and the interdisciplinary and eclectic range of its activities have presented critics and commentators with multiple problems. Previous cultural, performance and theatre histories have situated Welfare State in various categories - often depending on the orientation of the writer. For example, in an important early survey of performance art and happenings published in 1974, the artist Adrian Henri described Welfare State, first, as an 'art-orientated pop group' and, latterly, as 'anarchic street theatre'(Henri, 1974, 118-19); whereas, writing in the context of 'experimental' and 'fringe' theatre in 1975, theatre critic Peter Ansorge referred to them as one of the most highly regarded groups in 'the underground', providing the 'most spectacular instance' of what he termed 'environmental theatre' (Ansorge, 1975, 41-2). Reviewing the company's twenty-year history in 1988, Michael White made other associations.

Welfare State International's own twenty-year history as an outdoor travelling theatre may be read, in part, as a reclamation of public space as the rightful milieu and meaningful heritage of popular culture. Moreover, it is space in which to learn and create collectively an indigenous social poetry of a high order within a precise, functional context. It need in no way be parochial and purist, rather it is an eclectic receptive theatre, minimally verbal yet able to assimilate and articulate divergent cultural viewpoints through startling patterns of rich, evocative imagery. (White, 1988, 195)

White could not have foreseen that Welfare State would continue for yet another twenty years, but his comments provide a useful starting point for this re-examination. He also noted that, as 'indigenous animateurs', they 'consistently explored the territory between theatrical product and applied anthropology' (White, 1988, 196). Kershaw later commented that by the early 1980s, Welfare State's work was predicated on an 'iconoclastic radical ideology', shaped by a deep opposition to the overproduction and consumerism of the developed world (Kershaw, 1992, 209). Calling them 'primitive socialists', he wrote of their visionary, anarchic approach and 'their claims for the healing power of creativity and the place of "poetry" in a healthy culture' (Kershaw, 1992, 212). Pertinently, in the same text, Kershaw declared 'Welfare State was (and is) unique, impossible to pin down in any of the existing categories' (Kershaw, 1992, 212). 
In particular then, the 'hybrid' and 'in between' nature of Welfare State's creative output has perpetually posed difficulties for scholars attempting to position their practice. In this current re-evaluation, I want to dismiss the pressure to place Welfare State in one camp or another and to problematize some of the established critical binaries, as the familiar categories of alternative, oppositional, political, avantgarde, and so on, are not mutually exclusive. In her recent book on 'applied theatre', Nicola Shaughnessy argues this very point, declaring that this creative tension is a fallacy, a false dichotomy, and that such work is, rather, an interplay of formal experiment, affect and socialpolitical effect (Shaughnessy, 2012, 14). Her approach provides the most fruitful framework for a re-assessment of Welfare State. Her analysis of applied theatre draws on the vogue for what has been described within contemporary art practice as collaborative, interactive, immersive and participatory practice (Shaughnessy, 2012, 28, 188). Including them as key historical pioneers of 'applied theatre', Shaughnessy places the company in the 'hinterland between populist community carnival and exclusive experimental theatre' (Shaughnessy, 2012, 22-3; my emphasis). Furthermore, it is significant that Shaughnessy gives primacy to the discourse of participation for her analysis of their work.

The history of participatory art practices has been dogged by binaries, tensions and conflicts: equality versus quality, participation versus spectacle and art versus real life. As Claire Bishop, key theorist of the contemporary resurgence of participative art forms, has commented,

the dominant narrative of the history of socially engaged, participatory art across the twentieth century is one in which the activation of the audience is positioned against its mythic counterpart, passive spectatorial consumption. (Bishop, 2012, 36)

Welfare State crossed all those boundaries and dichotomies, generating what Norman Denzin has termed 'active spectatorship' (Denzin in Shaughnessy, 2012, 12). Bishop (2012) charts the historical shifts in re-imagining 'participative identity', from conceptualizing it as 'the crowd' through to current notions of audience as 'co-producers'. Welfare State pioneered co-production, as it was one of their key strategies. Particularly pertinent for this study, Shaughnessy's book addresses 'situated spaces between making and performance' and the contemporary shift from artist to spectator/participant. While any assumption of 'togetherness' must, of course, be problematized, drawing on Denzin's model and Shaughnessy's concept of 'socially engaged art praxis' (Shaughnessy, 2012, 7), I will argue that, through spectacle, collaboration and participation, Welfare State transformed communities into subjects not objects and that their practices demonstrated the possibility of 'emancipating the spectator' for action and even, potentially, for activism. Furthermore, in the new millennium, with the widespread coming together of carnival, festivity, activism and protest in the public sphere (Patrick, 2011) there has never been a better moment to reconsider Welfare State's significance, influence and legacies.

\section{History of the Company's Development}

\section{Origins and Formation}

[I]n many ways, Welfare State are the most daring of the Alternative Theatre companies because they are in the business of yoking together the aesthetic and visceral nature of theatre with a developing political analysis and at the same time of making that powerful conjunction available to people who have no interest in theatres or plays. (Coult, 1976, 20)

Welfare State was formed at the end of 1968, that momentous year of 'revolutionary' uprisings which has since acquired mythic status in popular memory. There is no doubt that the collective of artists, performers, musicians and assorted associates was a product of the radical political contexts and countercultural activities of the late 1960s. More specifically though, it emerged from the vibrant alternative cultural scene within and around Yorkshire, primarily under the creative impetus of one particular individual: Welfare State's future long-term artistic director, John Fox, then working at Bradford College of Art. Significantly, Fox did not have a background in theatre. A few weeks before Fox was due to take up a post as Liberal Studies tutor at Bradford, the Yorkshire Post carried a special feature on him in their series 'The Young Creators'. Fox was interviewed by Judith Hann at the remote farm in Coneysthorpe, near York, where he lived with his young family; Hann emphasized his versatility in the article. After studying Philosophy, Politics and Economics at Oxford and doing a teaching diploma, he spent four years studying Fine Art under Richard Hamilton and Victor Pasmore at Newcastle University, but promptly abandoned what looked to have been a promising career as a painter. 
For Fox, the 'fine art scene' was dominated by elitism, pretentiousness and festivals, he was and, having been involved in local happenings and festivals, he was motivated instead to that communicated with ordinary

At Bradford and around Yorkshire (Fox in Hann, undated).

minded people with experimental culte, there were plenty of likeIn 1980, Robin Thornber, the great deal of creative energy being at that time, argued that Yorkshire was 'based one engy being released in and around West and John and Sue Fox's Welfarus between Albert Hunt, Jeff Nuttall the Northern, provincial Welfare State' (Craig, 1980, 173-4). Indeed, scene was frequently highlighted in-metropolitan character of this for example, Adrian Henri nted in various contemporary accounts: work in England is today beited that the most exciting mixed-media (Henri, 1974, 118-19). The circle ared by young artists in Yorkshire' and Margaretta D'Arcy - The circle around the Ardens - John Arden performances and alternative been involved in a range of radical early 1960s, such as the 'Festive community-based activities since the Kirbymoorside, in 1963. Furthal of Anarchy', which they had staged at Leeds provided key contexts for the found art colleges at Bradford and Welfare State. Jeff Nuttall, artist the founding and future expansion of Show, also worked at Bradford. performer and founder of the People Leeds Polytechnic alongsider. Fox and Nuttall then both taught art at and poets such as Stuart Be plethora of visiting performance artists Whiteley, 2011-12). Initially, Bradford

Albert Hunt, the radicalded the opportunity for Fox to work with participatory forms of theatre Greatly and pioneer of experimental and A. S. Neill, in May 1965 Hunt Greatly influenced by the radical educator free rein and the full support of the the staff at Bradford, where he had anti-authoritarian project-based the Principal to set up an experimenta moving to the post atect-based 'liberal studies' programme. Before youth theatre while lecturing at Hunt had initiated an experimental as tutors, Fox helped Hunt at Shrewsbury. In 1967, with the Ardens An October Carnival, a happening-style ersburg 1917/Bradford 1967: Revolution on the streets of Bring-style re-enactment of the Russian from all over Yorkshire (Ho Bradford and involving over 300 students project). By the time Fox intitiated Hunt interview, Unfinished Histories different configurations with various othe State, he was also working in as Cosmic Circus, formed various other artists and musicians, such extensively with that company Mike Westbrook who later also worked a multimedia exploration of outer space that later formed the basis of a large-scale Welfare State event to herald the first day of spring in March 1970. In the mid-1970s, artist and singer Kate Barnard (who was later to become Westbrook's wife) painted the designs on the travelling trucks and caravans at the Heasandford base at Burnley.

Above all, in the early days, Welfare State was not an isolated group by any means. In the 1970s, it expanded the range of experimental UK-based performance practices, but, more pertinently, it emerged from a rich seam of Northern activity, much of it based around the 'Yorkshire Vortex' (see Nuttall, 1979, 68-9), which included groups such as the Yorkshire Gnomes, Al Beach's John Bull Puncture Repair Kit and Jeff Nuttall's People Show. Many of these individuals and groups collaborated or shared platforms at the end of the 1960s and early 1970s. For example, in November 1970, the John Bull Puncture Repair Kit and The Welfare State presented 'SCAB, a dazzling entertainment in memoriam of Sandie Shaw' at the AUE Union Club in Halifax. A leaflet publicizing the event, promoted by Amnesty International, noted 'a joint production for "Prisoner of Conscience" week which this year highlights the fate of Trade Unionists imprisoned for their views' (WSTC, 1970, 14/2).

Throughout the key decade of the 1970s, the activities of Welfare State can be viewed in distinct phases: the first few years were spent developing forms of nomadic and processional-style street theatre and spontaneous happenings; from 1973 to 1979 they worked from a settled encampment at Burnley; the turn of the decade and 1980s marked a move northwards and the development of participative work and deep immersion within the community in and around the industrial town of Barrow, culminating later in the building of Lanternhouse at nearby Ulverston in the 1990s.

\section{Nomadic Street Theatre and Impromptu Performance, 1968-72}

The Welfare State is in many ways the most remarkable mindblowing group of all. It contains many elements, art school, rock culture, music, pagan ritual - all fusing into a poetic Dionysiac vision of man liberated by revolution. (Hammond, 1973; WSTC 12/1)

The dozen or so artists, teachers and others working around Bradford brought together by John Fox in December 1968 shared a radical outlook and a common commitment to take art into the streets 
- early members included Roger Coleman, Roy Dodds, Jane Durrant, Alison Fell, Sue Gill, Steve Gumbley, Nigel Leach, Lizzie Lockhart, Ken McBurney, Rick Parker, Jamie Proud, Rosemary Timms, Chri Timms and Geoff Walker. Beyond that, the initial artistic strategie and aesthetic vision of Welfare State had a range of roots, amalgamating popular folk cultures and esoteric avant-garde art forms. Early happening-style events bore the inspiration of Flurus, Jorms. Early and John con groups Equally, the radical political ethos of internationa groups such as el Teatro Campesino, San Francisco Mime Troupe an the US-based Bread and Puppet Theatre were important influences.

Aside from these international references, a key characteristic wa the way in which Welfare State drew on British (or more particularly English) folk traditions and contemporary popular culture. Looking back, John Fox perceptively described them as operating 'somewhere between populist performance art and applied anthropology' (Fox, 2006). Mummery, for example, was particularly important. Referring to it as the 'last vestiges of English folk culture' Bim Martant. Referring to the basic scenarios of mummery as challenge, conflict, death and life renewal, all of which were key elements in various Welfare State performances (Mason, 1992, 118). Often improvising and expanding on a basis of rehearsed material, their performances, happenings, events and assembled environments incorporated staple elements from circus, pantomime, puppetry, music hall, festival and carnival, as well as earlier historical cultural forms like court masque and pageantry.

Aptly, Welfare State's first major event, Heaven and Hell (December 1968), commissioned by Lancaster University, was a day-long tribute to William Blake at the Ashton Memorial, involving over a hundred performers, a dancing bear and puppets. Street events and performances followed, often involving acrobats, wrestlers, muscins, performances dancers. sucers. A number of spontaneous events and impromptu processions, such as those through Leeds, were largely unrecorded, captured in the occasional photograph, but mainly in the memories of local participants and art students.

Many early events were akin to happenings transposed into medieval times. In a three-week project, in 1970, at the Beaford Centre in Devon - billed as 'medieval happenings, circus acts, etc' with cabaret and sounds by Mike Westbrook - rubbish was scrounged from tips and series $14 / 2$ ) create a Horror Maze and a Geodêsic Dome (WSTC series 14/2) Another typical event in March 1970, heralding the first day of Spring, included music provided by the Westbrook band, a team of racing cyclists and fencers, climbers, weightlifters, army radio operators, a model aircraft display, scaffolds of towers, giant projected images, thirty drum majorettes and a fancy dress pageant. With a pre-punk penchant for horror, in May of the same year, a Welfare State event entitled Heptonstall was described in the company's publicity as 'gothic entertainment',

a simple family circus is invaded by the dead from the Doomsday village of Heptonstall $[\ldots]$ strongmen, dancers, unicyclist and harlequin of life do battle with the King of the Dead, primitive ghouls, and Wild Electronic noise, films, slides and giant puppets. (WSTC, 1970, 14/2)

de an enormous contribution, whether it was the rough acoustic strains of the ramshackle twenty-or-so strong Bloodthe rough acoustic strains of heranting melodies composed for specific stained Colonial Band or haunting melodies composed for specific performances. Sometimes music would be spontaneously produced, lasting just one show, but often compositions would be layered into later pieces, producing an ever-growing patchwork, a 'source-pool' of sound. 'Mad Song', for example, composed by Westbrook with Fox of soun in the early 1970s, was used over and over again, metamorlyrics in the early 1970s, was used over and overue' in the Doomsday phosing into the 'Falcon tune and song in 'Bellevue' in the Doomsday Colouring Book tour of 1982 (Welfare State archive). Welfare State's musical repertoire was extensive and it is impossible to do justice to the role and range of it here (see 'Street and Outdoor Performance and the role and range of is iscores and Appendices listing LP albums (including John Peel's Top Gear Selection, BBC Enterprises 1969, and Welfare State/Lol Coxhill, Virgin 1975, in Coult and Kershaw, 1990, 31-57, 262-4, 269-70).

From 1968, a string of exceptional individual musicians, such as Lol Coxhill, Phil Minton and Mike Westbrook, played key roles in Lol Coxntribution to a peculiarly cumulative eclectic house style which combined fey English folk, Dixieland jazz and Albert Ayler-esque improvisation, Eastern and Dixieland jazz and Albert Aysers a smorgasbord of ethnic music. Rather than abackdrop to performance, music was used to heighten the intensity than a backdrop to performance, Players were often required to perform in punishing prolonged 'vigils': for example, the extensive performance in punishing prolonged vigis. For Colin Wood at the Memorial for the by Lol Coxhill, Lou Glandfield and Colin Wood at the Memorial for the First Astronaut, a static sculptured space in the Lancashire countryside (recorded by Mike Kustow in his film, Stoneyholme, for London 
Weekend Television's Aquarius series, 1975). Frequently, Welfare State soundscapes took on a shamanistic role while, at heart, the ethos was always about facilitating a connection between professional and amateur models and creating a common musical language.

We aim not to lower our standards but to broaden them by creating the Decathlon. We seek a diversity which is itself professional, but which allows each separate activity to be amateur, in the best sense. Ultimately, we are looking for a new Primitivism, where the shaman gets his ticket by vision, rather than Primely professional expertise. Welfare State's music is central to the establishment of that vision. (Coult and Kershaw, 1990, 57)

The rapid development of impromptu, processional and nomadic street theatre reached a climax in 1972 with a series of events and occurrences: a mammoth series of thirty outdoor theatre performances in rences: a mammoth series of thirty outdoor theatre performan' the invention of the complex multi-layered character, Lancelot Icarus Handyman Barrabas Quail. The appearance of Jamie Proud's alter-ego Handyman Barrabas Quile silled in Lelfare State's 1973 Beauty and the Beast, as a leaflet that accompanied Welfare State's 1973 Beauty and the Beast, as 'Britain's new folk hero (a working-class hermaphrodite strong-man)' Quail, a New Age everyman, became a recurring reference point for the company and featured right through to the final performance in 2006 In September 1972, Welfare State spent a month conducting the Travels of Lancelot Quail, a processional theatrical event which roved from Glastonbury through Somerset, Devon and Cornwall, culminating afloat on a submarine off Land's End.

We placed standing stones on remote tors, built turf circles on dark moors. Erected a maypole at night on a granite outcrop (for the autumnal equinox), lit giant beacons on inaccessible hills, walked twelve miles across Dartmoor at night, created a symphony in the Cheesering quarry with the Mike Westbrook Band, falling rocks and fire bombs. We have performed to all the cars on the A38 between Glastonbury and Burrow Mump in one afternoon. We have created a a chedrin naming ceremony for a child in the Hurlers Stone Circle Moor, tried Judge Jeffreys in an ornamental fountain in Taunton, and more or less discovered the sunset in Her Majesty's Submarine, Andrew. (Henri, 1974, 119) Fox's description of the south-west tour, recorded in Henic troupe's in 1974, captures the postmodern nature of the nitics were impressed bricolage of bizarre activities. Contemporaneous critics were impreir stories by Welfare State's makeshift approach, the poignancy of

and the wondrous spectacle of the images they created.

Dirt, a hand to mouth existence and makeshift props are the raw materials of a show concerned only with being alive [...] it was materials of a show concerned ond weird, gentle and tempestuous, a lifting and ebbing sea of stories. It is undecided and ambivalent, the bold stories touching

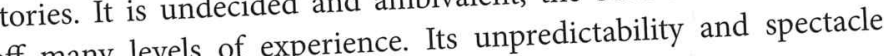
complete wonder. (WSTC, 1972, 12/1)

Finally, 1972 was also significant for the production of the first Welfare State 'manifesto', a political form of rhetoric in itself. Although many (for example, Parliament in events had obvious revolutionary denied any direct political engagement. Flames) their statements usually denied any direct

Why are you called Welfare State and are you political?

We started with the name seven years ago and it is now well known. fact, we offer assistance to the national imagination rather than agit-prop. People have a need for ceremony in their lives. Our vision (Welfare is to make theatricalc

In interviews in the 1970s, John Fox acknowledged that the right says we are anarchists and the left says we should be reaching the workers'. Denying interest in agit-prop, he argued that their activities were designed to any interest in agit-prop, he argued that their activities wery have poetry, that they were engaged in 'missionary wo Theodore Shank in The Drama Review, March 1977 in Itzin, 1980, 72). Never didactic, the political ethos of Welfare State was embedded in the organ manifestoes professed this 'alternative aesthetic': a unique hybrid approach which combined archetypal myth-making, a Blakeian vision typically reflected in 1960 ' counterculture and a New Age rhetoric of magic and ritual.

The Welfare State make images, invent rituals, devise ceremonies, objectify the unpredictable, establish and enhance atmospheres 列, situations and people [...] We will 
continue to analyse the relationship between performance and living, acting and identity, theatre and reality, entertainment and product, archetype and need.[...] We will react to new stimulus and situations spontaneously and dramatically and continue to make unbelievable art as a necessary way of offering cultural and organic death. (Welfare State, 1972, n.p.)

From Civic Magicians to Engineers of the Imagination, Burnley 1972-1979

Through the classic period of the 'proliferation' of alternative theatre in the mid-1970s (Kershaw, 1992, 87), Welfare State worked out of a settled base in Burnley, a working-class industrial town with growing Asian population, captured on camera by Daniel Meadows, who documented many of the company's events in that decade. By 1972, the company was already established in Burnley but the collapse of plans to stage an exhibition event in London at the Serpentine Gallery (primarily because they were refused permission to erect their circus tents in Kensington Gardens in Hyde Park) convinced them to stage the event in Burnley instead. Annoyed with the intransigence of the authorities, Fox sent a telegram to the Serpentine, explaining why he had cancelled the planned event; he also despatched a set of photographs of work for them to paste on the gallery floor and, provocatively, a mynah bird, trained to say 'Fuck off bureaucrats!' - apparently, it didn't survive the journey (Fox in Whiteley, 2014).

The company set up their touring caravans and lorries on a reclaimed rubbish tip at Heasandford quarry in Lancashire, and ended up staying five years as part of the Mid-Pennine Association for the Arts' innovative community programme of artists' residencies. Until 1978, with Boris Howarth and Lol Coxhill playing key artistic roles, the company built a self-sustaining community of growing families and associated artists, musicians and performers. For the company, this was an exceptionally productive period in which, besides conducting an experiment in alternative forms of living and social interaction, they created some of their most important and influential performances and developed new artistic strategies and prototypes for vernacular art forms.

The company focused on working in dialogue not only with the local landscape but also with the town's working-class communities. On 1 January 1973, in nearby Barrowford, Welfare State had created an event to celebrate the New Year, leading 'a cavalcade to display the coracle of the dying hermit', burying a canister of 'relics' and planting trees. This led to an invitation from the Council to return to create a midsummer event and the coining of themselves as 'civic magicians', a tag quickly adopted by others. Following a visit to Heasandford, Ian Nairn, a London-based critic, recognized Welfare State's aim to create a 'sense of wonder', quipping that there had been two 'wonders' for Burnley that year: the 'Civic Magicians' and their 'happenings in a disused rubbish tip' and promotion to First Division football. (WSTC, 1973a, 12/1). Clearly, the local population was variously bewildered and confused by the company's activities, but they were also sometimes beguiled into participating.

Most of the audience-participants at Burnley were children and I'd be prepared to bet that ten years ahead, in bank or factory, someone will think back to that crazy evening when Icarus wed the Queen of the May and wonder what the hell happened to wonder. (WSTC, 1973a, 12/1)

A series of key performances and iconic events followed. One of the first projects, Beauty and The Beast, featured the mythic figure Lancelot Quail. Described by Robin Thornber as 'like being in one of those nightmare landscapes by Hieronymous Bosch' (WSTC, 1973b, 12/1), the company spent three months building a makeshift labyrinthine environment from junk for the final performance.

Much of the audience was street kids. Mostly they just jeered and jibed, their defence against anything unfamiliar [...] we may not accept that anything that happens on a rubbish tip could be a major cultural event. But in their lives at least that's just what it was. (WSTC, 1973b, 12/1)

In November 1973, they created the first large-scale bonfire event, directed by Boris Howarth, which later developed into Parliament in Flames in Burnley (1976) garnering an audience of 10,000; it was then recreated in Milton Keynes (1978), Ackworth (1979), Tamworth (1980) and, finally, Catford (1981) with 15,000 spectators. Subsequently, there was a suggestion that they create a similar event in Milton Keynes Bowl for an audience of 50,000 but, significantly, the company rejected the idea of working on a spectacle of that scale (Fox in Whiteley, 2014). In 1974, they made their first permanent 
earthwork at Gawthorpe Hall in Burnley and their first giant ice work at Wath-upon-Dearne. In the following year, they created Harbinger, a large-scale sculpture from scrapyard junk, for the International Performance Festival in Birmingham city centre. Besides outdoor site-specific projects, they also worked in galleries - for example, with Bob Frith of Horse and Bamboo Theatre, they constructed a fully operative Ghost Train at the Mid-Pennine gallery in Burnley in January 1977. The Burnley period culminated in Barrabas, a six-week project, described as a 'total theatrical environment' in which daily performances included film, sideshows, processions and the 'ritual, disembowelling of The Dead Man (and his culture)' (Coult and Kershaw, 1990, 245).

Beyond the Burnley site, Welfare State's ambitious and audacious approach to creativity was mirrored by their efforts at social engagemen in some of the most deprived communities in Britain at the time Typically, in August 1976, the company spent a weekend setting up their tents and equipment on a squalid site at Denistone, a povertystricken area in Glasgow, in readiness for a procession through the working-class streets, and a finale performance of Island of the Los World. A commentary, made at the time by Fox, noted the problems of working in a locality where violent gangs and knife crime were rife: lots of equipment went missing overnight and local children fought over tickets. With little if any cultural provision, live theatre was virtually unknown, and the company faced insatiable demands for their performances. Fox's efforts to highlight the social and economic deprivation of the area, and his call for funds to set up a community theatre at the request of the local community, aggrieved the Lord Provost of Glasgow so much that Fox was asked for an apology, and the Arts Council was asked to investigate the company's subsidy. With the Arts Council's support, the controversy dissipated, but the incident is indicative of some of the ethical and political issues surrounding the field of social theatre in the 1970s (ACGB, 1976a, 34/163/1).

Besides creating events in and around Burnley, and carrying out various commissions and tours in the UK, Welfare State also worked in Europe through the 1970s. Their first overseas project in January 1973, Fanfare for Europe, involved a travelling performance that started in Hull Market with a 'paranoid clown' and his wife selling tripe and onions. It continued on the North Sea ferry and culminated in a procession in Rotterdam. In summer 1973, they performed another version of Beauty and the Beast at the Shaffy Theatre in Amsterdam and De Lanteren in Rotterdam. In 1975, midway through the residency at Burnley, notes made by Fox reflected on their various performances in Holland and on the expanded concept of Quail. Significantly, one of Fox's commentaries, written at the time, reveals some of the aesthetic shifts that had taken place in the work of the company, signalling a new set of preoccupations.

Now, parody has gone. Now Quail seeks to extend and confirm his identity in relation to purer elemental forces of ice, fire, water and earth. WS now spends much time constructing large landscape sculptures - sometimes without performance of any kind but more usually with climactic musical and processional animation. Illusion has gone. Tangible form has increased. Work exists in landscape. Rarely in theatres. Now, WS is seeking through Ritual Patterns Archetypal symbols Simple concrete images and necessary ceremonies to make a holy but secular theatre accessible to the common man. By travelling in a tribe...usually with a mobile village of lorries and caravans $[\ldots]$ the implied relationship between alternative life style and metaphysical poetry is demonstrated. Imagination and play shown in action and objectified in artefacts present a real counter to the tedious illusion of materialist death culture. Now Quail is doing it. Not commenting upon it. A mythical tribe grows round him. Quail becomes maybe the harbinger of the future. (WSTC, 1975a, $12 / 1)$

An earlier note by company member Peter Kiddle expressed the view that Welfare State was not being as effective as it could be in communicating and engaging with the community at large, or with local youth many of whom were articulate and keen to talk about what was going on - 'no A stream kids these, but stuck somewhere down the alphabet and stuck in school by ROSLA': at the time, the Raising of the School-Leaver Age adversely affected a generation of young people, many of whom had no interest in staying on at school (WSTC, 1937c, 12/1). Kiddle suggested setting up discussion groups and print and filmmaking workshops as a way forward. Others had different views. By 1976, a series of aesthetic and directional differences had developed within the group and a number of individuals, including Steve Grumbley and Lizzie Lockart, split off to form the theatre company IOU (Independent Outlaw University). In 1978, the Burnley base was dismantled and the nomadic on-site Welfare State 'school', which had intermittently taken in local children, folded with it. With Welfare State members registered as 'home teachers', the company's own school had operated since 
April 1975. Catherine Kiddle's book recounts the ethos, benefits and problems they faced in running the school.

So what should we teach these children for whom we now had total responsibility? Knowledge, facts, experience yawned before us, the great blackness of space, infinite and impossible to comprehend. Our own knowledge, our skills, our own moments of excitement and illumination in learning shone out like stars [...] We wanted to give them the stars. (Kiddle, 1981, 32)

The Fox family went to Australia on a 'sabbatical' residency and the company base moved to Liverpool where Boris Howarth worked with Adrian Mitchell to produce Uppendown Mooney. On return, in 1979, the Foxes settled in Ulverston with a core group of five full-time employees and over fifty freelance contributors and this initiated a new phase of work starting, for example, with the first Summer School, in 1980.

\section{Early 1980s Onwards}

The work of Welfare State from the 1980s to 2006 is outside the scope of this volume. While Kershaw and others have documented the company's prolific output through to the late 1990s, a comprehensive survey and further research needs to be done. However, as has already been indicated at the outset of this chapter, various key developments occurred in the early 1980s and a brief reference, at the very least, is necessary here. Paradoxically, it was in this period that Welfare State combined participation and epic spectacle in a creative symbiosis which, eventually, became unsustainable. The shift to Cumbria represented a desire to establish a permanent base and deep community roots from which to develop new forms of socially-engaged participative practice, but it also coincided with an ever more ambitious programme of largescale spectacular events (see Kershaw, 2007, 135-6), such as the final Parliament in Flames at Catford (1981), Raising the Titanic, Canal Dock Basin, Limehouse (1983) or, overseas, Tempest on Snake Island, Toronto Theatre Festival (1981) and The Wasteland and the Wagtail, performed on a mountain side in Togamura, Japan (1982). Later large-scale projects included False Creek: A Visual Symphony, a six-week residency in partnership with Canadian artists and musicians at World Expo '86 in Vancouver, Glasgow All Lit Up (1989-90), Shipyard Tales (1990) and Lord Dynamite (1991). Two documents by John Fox, A Plea for Poetry (a paper to the National Arts and Media Strategy Unit) and Flight From
Spectacle, both in 1991, signalled a shift in the direction and ethos of the company. As Mason has noted, these events and performances were not only 'site-specific', they were also 'audience-specific'; going beyond the performance, they were about creating a particular audience, often having worked together for weeks on a creative project in technical and craft-based workshops (Mason, 1992, 134).

Welfare State worked extensively with local participants around Ulverston, initiating the annual lantern festival and extending their locale to include Barrow-in-Furness, a town with an economy based on shipbuilding and the manufacture of nuclear submarines and with long traditions of working-class organization and culture. Between January and April 1982, they collaborated with Sheffield City Polytechnic on a full-length 'community feature film', King Real and the Hoodlums, based on a script (derived from Shakespeare's King Lear) by Adrian Mitchell with music by Peter Moser, mainly filmed on location at Barrow with unemployed local youth. The anti-nuclear narrative had an overtly subversive impact in Barrow, a town whose economic survival depended on making weapons of mass destruction (Kershaw, 1992, 215). Local reception was mixed as King Real played with the contradictions of the town's industrial and economic situation.

Audaciously, the company continued their risky strategy of creating ironic 'ideologically double-edged' events (Kershaw, 1992, 220). In 1987, at the invitation of Barrow Borough Council, Welfare State spent six months creating a 'sculptural enhancement' of the Town Hall, which turned out to be 'probably the biggest artwork in Europe' (Thornber, 1987). This was spectacle on a grand scale, with a market, an oratorio composed and collaged from traditional songs by Peter Moser sung by a mass choir, an exploding birthday cake, pyrotechnic displays and acrobatic performances on the building itself. As Kershaw notes, Town Hall Tattoo was extraordinary for its 'rich ideological dialectic' (Kershaw, 1992, 220) and for the way it integrated civic celebration, anarchic imagery,

and a subtle radicalism which poked gentle and good humoured fun at the very values the event appeared to valorise. This was ironic agit-prop on the grand scale, heavily disguised as a straightforward carnivalesque party. (Kershaw, 1992, 220)

Garnering an audience of 15,000 , the event was hailed as a critical success and Barrow Council went on to fund Welfare State to work with the town's community for a further three years, culminating in the Feast 
of Furness in July 1990 - a 'total festival' which included story-telling, potry the Boat', an anarchic nightclub. The centrepiece of the festival was Shipyard Tales, a cycle of plays, devised by local young people and adults, which explored the complex moral issues and paradoxes of a community whose economic survivare (Fox, 2002, 119). In particular The Golden Submarine provided a typically spectacular finale, a multilayered work that was simultaneously humorous, celebratory and subversive. Welfare State's efficacy in utilizing the rhetorics of theatre, intertextual narrative and participatory practices enabled them to create performances and events that revealed socio-political contradictions and complexities through the kind of 'active spectatorship' referred to earlier. As Kershaw notes in a detailed analysis of this and other participative spectacles created by Welfare State at that time despite the danger of creating a 'tokenist nod to towards self-determination and empowerment'

Far from being a crude escapist event, the Golden Submarine was a grand carnivalesque agit prop, participatory celebratory protest, perhaps at its most powerfully subversive. (Kershaw, 1992, 237-40)

\section{Funding and Company Structure}

Reflecting the flourishing of British 'alternative theatre'. in the 1970s, by the early 1980s Welfare State had grown rapidly from a small 'underground' nomadic troupe to an established company with all the trappings of a business outfit. As Craig put it crudely in 1980, the continual challenge for them, as for others, was 'to set a course between the Scylla and Charybdis of incorporation into the mainstream and cultural ghettoization' (Craig, 1980,10). There is no doubt, though, artistic integrity, while accruing funds and subsidies from various organizations.

A number of factors assisted the development of alternative and political theatre in the 1970 s - for example, the development of porition and community-based, non-theatre venues. The gradual increase in public subsidy from the Arts Council, and its recognition of new and alternative categories of drama and theatre-related activity, were key factors for Welfare State. The minutes of the Arts Council's Drama Panel at the end of the 1960 document the emergence of 'Fringe and Experimental' theatre with, in 1968 , a specific reference to an 'upsurge' of activity, initiating the setting up of a 'New Activities Committee' (ACGB, 1968, 43/3/1). In common with various other multimedia groups operating at the time, Welfare State was able to capitalize on the fact that the Arts Council's bureaucracy was not quite ready to cope with the interdisciplinary nature of their work. Earlier, apart from the 'New Activities Committee', Welfare State had applied to the Jazz Subcommittee but, as Nick Barter commented in 1973, although they were likely to be funded by the Drama Panel, their work could also attract funds from the Experimental Projects Committee, and Visual Arts, noting rather emphatically that the Arts Council needed 'to avoid triple subsidy' (ACGB, 1973, 41/78/3).

Welfare State's earliest approaches to the Arts Council for funding were via the New Activities Committee, with their first request for a capital grant to pay for the purchase of a piano amplifier and speakers: an amount of $£ 375$ was awarded in September 1971 (ACGB, 1971, 41/78/2). The company's correspondence with the Arts Council through the early 1970s documents a litany of appeals for further funds, usually in response to urgent requests to fund vehicle repairs, as was the case following their South West tour in 1972, after which Fox noted they had serious financial problems (ACGB, 1972, 41/78/2).

In 1973, the company registered as Galactic Smallholdings Ltd, an educational charity to act as an umbrella organization for the company to 'initiate research projects into the aesthetics of the alternative' (WSTC, 1978a, 12/1). By 1973-4, at their council-supported base at Burnley, with almost 150 performances and events supported by an Arts Council grant of $£ 14,300$, the assets - and liabilities - of the company had become extensive. Supporting documents for funding applications to the Arts Council in the mid-1970s are illuminating. A document, dated 1975, gives a breakdown of grants, expenditure, debts and staff costs, noting that no one received more than half the Equity minimum and the Director, John Fox, was unpaid (WSTC, 1975a, 12/1). It summarizes the company's previous funding: 1968-9 nil grant/41 performances, $1969-70$ nil grant/38 performances, $1970-1 £ 133 / 87$ performances, $1971-2 £ 2,697 / 109$ performances, $1972-3 £ 8,570 / 146$ performances, $1973-4 £ 14,300 / 143$ performances. With two lorries, one Landrover, one Bedford van, a generator and trailer, and with the north-facing Heasandford site in dire need of hard standing and a WC unit, proposed capital expenditure of $£ 35 \mathrm{k}$ and expected running costs totalling $£ 7,742$ for 1973-4 (WSTC, 1973d, 12/1), even though the company had 
secured one of the largest public grants in the sector, the continual shortfall of funds to sustain basic living conditions was clearly a major issue. Another document, 'The Welfare State: A Report on the Future' dated July 1974, gave the total estimated grants for 1974-5 as $£ 43,200$ - this included money from 'Housing the Arts' and the Gulbenkian Foundation (WSTC, 1974, 12/1)

In 1974, outlining plans to replace the earlier concept of the 'mobile village' with a 'residential nucleus', their pitch to the Arts Council for almost $£ 50,000$ hinged on extending both international and participative elements of their work, indicating a potentially fruitful symbiosis of Welfare State's ideological aspirations and public funding policy (WSTC, 1976, 12/1). Even with generous subsidies, the company continued to have cash-flow problems through the decade and the Arts Council generally responded with additional guarantees against losses. On occasion, the company's administrator had to make additional requests for an advance out of the guarantee, to ensure that performers could be paid (ACGB, 1978, 34/163/4). Nevertheless, the company managed to thrive and, with astute financial management, continued to attract public subsidies. By the end of the 1970s, Welfare State was running a large-scale operation with permanent and freelance employees, company directors and an administrator.

The Fox family's 'sabbatical' year in Australia offered a breathing space for the company and, reconfigured and refreshed, Welfare State moved to Barrow-in-Furness in the early 1980s. Policy statements and accompanying documents submitted to the Arts Council in 1979 underlined a shift of emphasis from 'box office returns' to 'grassroots work', with Welfare State planning to focus more on educational and community-based work - a change of direction which, Fox indicated, would require appropriate subsidy,

Our argument is simply that we have essential work to do for which we are uniquely qualified [...] unfortunately even after 11 years of positive creation our original art is still peculiarly vulnerable to the vagaries of unbalanced not to say unhinged free market forces [...] if we can presume to be valued as a national asset, then may we please be funded accordingly? (ACGB, 1979, 34/163/4)

Consistent work in the community in the area through the next decade subsequently led, in 1999, to the Lottery-funded building of a permanent base for performance, educational and community projects, Lanternhouse at Ulverston. While this represented the culminating achievement of over forty years' work, in many ways it signalled the beginning of the end, as a combination of restrictive legislation, endemic managerialism, the recuperation of 'alternativity' by capital and the corporatization of culture constrained both the aesthetics and eventually, the ethos of the company. From April Fool's Day 2006, John Fox and Sue Gill archived the company, handing it over with full funding to another organization under the name of Lanternhouse International. Subsequently, Lanternhouse continued to operate as an independent company and, occasionally, a community resource. A poignant coda to this study: it closed in April 2012 and, as I write, the building has been put up for sale.

\section{Artistic Policy and Working Method}

Most alternative and political theatre groups emerging from the countercultural scene of the late 1960s were purposefully challenging the dominant methods of cultural production and management. As a collective of artists, musicians, engineers, writers, teachers and poets, Welfare State, with its collective and collaborative approach, was no exception to that. While there were designated 'directors', and particular individuals were given specific roles, the company maintained an anti-hierarchical and egalitarian approach to all aspects of its work. Although specific skills and experience were acknowledged, everyone was encouraged to perform, make music and assist with artistic and technical production.

Collectivity extended to the working methods used to create performances. A substantial Welfare State document entitled 'The Welfare State Internal and External Environment' (WSTC, 1975b, 12/1) outlined 'the decision making process' at great length and in some detail, and suggests that, in theory at least, they aspired to democratic aims. It noted that the company was a collective of individuals sharing a common aim, although it also aimed to provide aesthetic freedom for other work. Aesthetic and ideological tensions were already evident at this time though, and issues came to a head in 1976. In particular, archive documents show that, apart from ongoing financial problems reaching a critical point, a key issue related to some individuals wanting to carry out creative work outside Welfare State, and this led to a group of company members proposing recommendations to instigate a small committee to control the artistic directions of the company (ACGB, 1976b, 34/163/1). An internal Arts Council memo dated March 1976 
warned, alarmingly, that Welfare State was 'about to implode' (ACGB, 1976d, 34/163/1): clearly, there were divisions created in respect of how the company should be run. By August 1976, a number of changes had been made to company personnel, and a Belgian, Luc Mishalle, took over from Peter Kiddle as full-time administrator. Mishalle, a musician who had originally trained as an arts administrator, joined Welfare State while doing his 'national service'. As he was a conscientious objector, social work for an arts organization was allowed instead of military engagement. By 1976, as far as Kiddle was concerned though, the personnel management issues previously highlighted for concern by the Arts Council had been dealt with amicably and efficiently. Pointedly, in a letter to Clive Tempest at the Arts Council, Kiddle noted that it had had 'considerable problems' but that Welfare State actually presented a 'model of good management' in the way they had resolved 'industrial problems and changed administration' (ACGB, 1976c, 34/163/1).

That said, in May 1976, Steve Gumbley, Liz Lockhart, Di Davies and Lou Glandfield left to co-found IOU with others. Initially, IOU worked under the umbrella of Galactic Holdings, finally becoming a wholly independent company on 1 April 1977. With a main administrator and no regular policy meetings, the main area for Welfare State's collective activity was concerned with the process of aesthetic decision-making. A typical scenario would be as follows:

Once gig is in advanced state of negotiation, John Fox visits site with a couple of others. Reports impressions back to company - then we arrive on site. Each person is allotted task. John oversees. (WSTC, 1975b, 12/1)

At that time, 'scripts' were largely a written indication of how Fox, as artistic director, visualized the performance, Rather than detailed directions, they were usually treated as guidance notes, with little formal rehearsal. Writing in the San Francisco Theatre Archive in 1978, about the working methods of various experimental theatre companies, Theodore Shank focused on Welfare State's emphasis on the construction of site-specific scenarios, rather than prepared scripts (WSTC, 1978b, 12/1). However, despite the total theatrical experience created, rather than action, the creation of single iconic imagery was of paramount importance for Fox. As he noted, 'we create ambiguous hermetic images which you can hang meaning on, but which don't have any meaning themselves' (Fox in Mason, 1992, 81). Visual aesthetics took precedence over language and, in many of Welfare State productions and performances, this was a major characteristic, as intimated in this vivid description by John Fox of a scene from the Vigil of Icarus:

$[\mathrm{O}] \mathrm{n}$ a great ziggurat of ice blocks in a sunken marble courtyard a wounded airman weeps at night. Candles are lit in the ice. A nun plays a flute, four cellists lay a lament for twelve hours. Meanwhile circling above the city a frail aircraft trails a painted illuminated backdrop of the wings of Icarus. (WSTC, 1973d, 12/1)

\section{Selected Key Works}

As indicated already, apart from archetypal figures such as Quail, Welfare State constantly recycled narratives and motifs. Striking images and talismanic objects commonly recurred in the company's productions. Apart from attracting critical acclaim and large audiences, Beauty and the Beast (1973) and Parliament in Flames (1976) were key works that functioned in this way and, in doing so, acquired a mythic significance of their own within the company's repertoire. The Mid-Pennine Association for the Arts issued a press release (written by John Fox) for the performance,

On a plateau above a polluted river skirting green houses, allotments, new factories and NCB sludge, the Welfare State settlement - a cross between a Bolivian tinmine, TS Eliot's 'wasteland' and an Inca stilt village - is growing and extended through scarecrows, subterranean tunnels and living vans decorated with mythical paintings of Beauty and the Beast.

Beauty and the Beast was the first major project in Burnley. It involved company members and locals spending three months creating a junk environment that, along with making bonfires, was a staple Welfare State practice. Later, the audience was led by Quail past the caravans painted by Kate Barnard (see above) with mythical figures and creatures, through a labyrinth that resembled a grotesque haunted house of horrors, to witness the staging of a cycle of promenade performances. In summer 1973, they performed another version of Beauty and the Beast at the Shaffy Theatre in Amsterdam and De Lanteren in Rotterdam. In late 1977, the company created The Loves, Lives and Murders of Lancelot Barrabas Quail on Fulledge Recreation Ground in Burnley as a kind of 
synthesis of all the previous years' experiences of Quail, the 'everyman character. In 1983, Tony Coult captured the experience and conveyed a sense of the imagery in such detail that it is worth quoting at length.

[I]n a complex of tents around what looked like a medieval jousting [1] n a complex of tents andered amongst sideshows and giant puppets space, the audience wandered amongst sideshows and giant puppets before entering a 'cinema' to see a film about Quail and his bizarre early life. After the film, there was an opportunity to wander again, to buy tea and hot potatoes, to investigate the strange tableaux representing Quail's inner mind, to listen to the band's music or just to keep warm by the glowing brazier. Finally, the audience sat on either side of the space for the 'play' of 'Barrabas'. Giant puppet figures, and acting performances to match called to the performance space an array of marvellous images to terrorise and torment Quail. As the performance drew to a close, two gross cooks distributed spicy, steaming-hot lardy bread to the audience. (Coult and Kershaw, 1990, 10-11)

Coult argued that 'Barrabas' was a summation of many Welfare State elements. With its universal themes of birth, death and resurrection, he notes that the imagery created was spectacular and beautiful, not because of its polish or perfection, but precisely because it was 'rich, quirky and obviously handmade' (Coult and Kershaw, 1990, 10).

In November 1973, Welfare State created their first large-scale onfire event that later developed into Parliament in Flames in Burnley (November 1976) with an audience of 10,000 people. It was an exhilarating spectacle with a revolutionary theme that combined affect and effect, particularly given its later restaging at the same time as mass the Thatcher

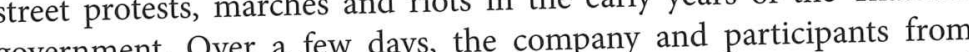
the local community built a sixty feet high replica of the Houses of Parliament, and a thirty feet high 'guy' which was then subjected to Parliament in Flames, directed 列 Wood Andy Plant, Tim Hunkin and Tony Lewery with pyrotechnics (1978), by David Clough, was then re-created in Ackworth (1979), Tamworth (1980) and, finally, Catford (1981), with 15,000 spectators. Although the event acquired the status of one of their 'vernacular prototypes', it retained an immediacy and volatility which, Bim Mason notes, is only possible outdoors where the environment is impossible to control (Mason, 1992, 85).

One of the company's most remarkable productions, King Real and the Hoodlums, was a community film made on a budget of $£ 25,000$ with a script by Adrian Mitchell. It was created on location in Barrow between January and April 1982, with the assistance of Sheffield Polytechnic and over one hundred and fifty local participants, many of them shipyard workers and unemployed youth with no acting experience. Made the year after the patriotic fervour of the Falklands War, in a town whose economy was constructed on the arms industry, the storyline took Shakespeare's King Lear and turned it into an overtly anti-nuclear fable.

The film combines the razzmatazz of Punch and Judy with the sad blue-greys of Goya. In its punk-operatic ex-cesses, icebergs of weldedtogether fridges float by under the shipyard cranes and Lear/Real's daughters totter up thrones of junk to preside over the last rites of consumerdom in a spirit of holo-caustic humour. (White, 1988, 195)

In what Kershaw describes as 'a kind of punk-medieval rabble in a wasted industrial junkyard' (Kershaw, 1992, 215), the three daughters conduct a quest to find what they describe in the film as the "keys of destruction' The scene in which Tom and Claudella wander in the 'wilderness' - a post-nuclear desert with a backdrop of factories, interjected with montaged images of derelict burning cities and industrial wasteland - is bleak but poignant, as they sing a simple haunting folk melody. Later, in the 'royal bunker', there is a scene of gluttony and feasting, as the power-hungry fat sisters (literally) squeeze out the King and fire him into space like a torpedo. Finally, the bunker blows up, Claudella throws away the 'keys of power' forever and the entire company makes a ramshackle musical procession back into town for a bonfire. Culturally tied to a post-punk 'Rocky-Horror' aesthetic, King Real and the Hoodlums is comical but, given its setting, context and audience, it is also boldly and radically subversive: another gloriously triumphant example of Welfare State's capacity to create 'ideologically double-edged events' (Kershaw, 1992, 220). The premier showing of the film at the local cinema was equally 'ideologically double-edged' and, by all accounts, a spectacular experience. After descending from a limousine, all the 'stars' made their entrance via a rather small 'red carpet. Consequently, Fox recalls that it took a long time to get everyone installed in the cinema and, with an ironic awards ceremony in which the whole cast each received a golden statuette, the evening was 'long, very joyful and exceedingly raucous' (Fox in Whiteley, 2014). 


\section{Looking Ahead}

Certainly, through the 1970s and into the early 1980s, Welfare State's activities were underpinned by a commitment to collaborative working, breaking down the barriers between lay and professional models and fostering a deep and lasting engagement with participants from local communities. Through the 1980 s, when many other companies were closing down, their affective events and performances developed new audiences and fostered 'active spectatorship'. Maintaining a sense of radical dissent, Welfare State revealed the ambiguities and contradictions of late capitalism, wedded to profit, consumerism, arms manufacture and the destruction of the environment. As was emphasized at the outset, the legacy of Welfare State is complex and conglomerate, as it spawned many other experimental theatre and performance groups. More interesting, perhaps, is the new 'performative paradigm' of the second millenium. Kershaw has noted that, 'the new global forms of political, economic, media-based and technological change engendered the performative society: societies that are crucially constituted through performance' (Kershaw, 2007: 11-12). In the last ten years or so, in a performative and choreographic turn, antiglobalization and direct action groups, such as the Clown Army, or the Black Bloc with its spectacular exploding Trojan Horse on the anti-cuts demonstration in March 2011, have adopted Welfare State-style strategies. Carnival, mass participation and spectacle have been used as a means of protest, resonating with some of those distantly remembered events that disrupted the status quo in the 1970s, when ice melted and fire burned.

\section{Endnote on Sources}

The research for this case-study utilizes the author's personal collection plus private papers and archives of John Fox/Sue Gill (author's personal access); the extensive Welfare State archive (including extensive collections of photographs) held as part of the University of Bristol Theatre Collection (referenced in this chapter as WSTC); and the Arts Council of Great Britain (ACGB) archive held at the Victoria and Albert Museum. In addition, the author drew on interviews with Welfare State company members and associates, some of which were conducted for a retrospective exhibition, Radical Mayhem: Welfare State International and its Followers, which she curated for
Mid Pennine Gallery, Burnley, 26 April-7 June 2008. The author's published conference papers include Whiteley, Gillian, 'New Age Radicalism and the Social Imagination: Welfare State International in the Seventies', in Laurel Forster and Sue Harper (eds), British Culture and Society in the 1970s: the Lost Decade, Newcastle upon Tyne: Cambridge Scholars Press, 2010, 35-50. Coult and Kershaw (1990) have a chronology of performances and events from 1968 to 1990; chronologies (some annotated by John Fox) up to 2006 are held within the Welfare State archive (WSTC). 